\title{
Antiviral Activity of Mangifera Extract on Influenza Virus Cultivated in Different Cell Cultures
}

\author{
Amin A.S. Al Rawi ${ }^{1 *}$, Hajir Sh.H. Al Dulaimi² and Marwa A.A. Al Rawi ${ }^{3}$ \\ ${ }^{1}$ University of Baghdad, College of Vet Medicine, Microbiology Department, Iraq. ${ }^{2}$ University of Anbar, College \\ of Sciences, Biology Department, Iraq. ${ }^{3}$ Iraqi University, College of Medicine, Microbiology and Parasitology \\ Department, Iraq.
}

\begin{abstract}
Medicinal plants interred in manufacturing the traditional medicine since very old times and were commonly used for the handling of bacteria, viruses and microbes diseases. In this study, we prepared four dilutions of $\left(10^{0}, 10^{-1}, 10^{-2}, 10^{-3}\right)$ mangifera extract. The four diluted extracts were treated with two types of tissue culture cells (primary fetal calve to culture of kidneys cells as well as chicken embryo fibroblast) to distinguish the extract. We found that the $10^{-1}$ dilution has the lowest cytotoxicity on the cells and the highest antiviral activity from the three other dilutions. To confirm this result, we used a real time PCR test to detect the quantity of the viral load yield (CT value). The positive control shows the CT value to be around 22 (group 3) which indicates to the high viral load (treated with $10^{-1}$ mangifera extract). A CT value of more than 28 indicates lower values of virus loading and showed the anti-virus activity to extract on influenza virus.
\end{abstract}

Keywords: Antiviral Activity, Mangifera Extract, Influenza virus.

*Correspondence: dr.alkarkhi@gmail.com

(Received: 10 January 2019; accepted: 13 March 2019)

Citation: Amin A. S. AL Rawi, Hajir Sh. H. AL Dulaimi and Marwa A. A. AL Rawi, Antiviral Activity of Mangifera Extract on Influenza Virus Cultivated in Different Cell Cultures, J Pure App/ Microbiol., 2019; 13(1):455-458 doi: 10.22207/JPAM.13.1.50

(c) The Author(s) 2019. Open Access. This article is distributed under the terms of the Creative Commons Attribution 4.0 International License which permits unrestricted use, sharing, distribution, and reproduction in any medium, provided you give appropriate credit to the original author(s) and the source, provide a link to the Creative Commons license, and indicate if changes were made. 


\section{INTRODUCTION}

Mango (Mangifera indica L.), which considered as a very common fruit belong to a certain kind of plants called Anacardiaceous, as well as papaya, avocado and banana, it is considered the King of all fruits in the equatorial area of the world like India which is considered as the world leader of these fruits. Its great popularity is because of good flavor as well as its testy and good looking in addition to its high nutrition importance ${ }^{1}$.

These fruits contained a very high percentage of antioxidant materials which gives a specific uses in reducing the risks of heart, cardiac's and cancer disease, in addition to that it shows a high activity against viruses ans microbes and prevent them from increasing ${ }^{2}$.

Every part of these plants including its leaves in addition to the fruit itself were applied and used and applied in biomedical uses. Studies indicate that mangoes possess as a treatment against diabetic, oxidant materials as well as viruses, cardiac in addition to its property as antiinflammatory material. Antibacterial, anti-fungal, anti hermitic, anti-parasitic, anti- tumor, anti-HIV, anti-bone re-sorption, antispasmodic, antipyretic, anti- diarrheal, anti-allergic, immuno-modulation, hypo- lipidemic, anti-microbial, epato protective and gastro-protective properties have also been observed ${ }^{3}$.

The presence phenolic complexes increase the uses in medicine applications such as pharmacology, immunology in addition to that, it can be used as wounds recovery compound besides its uses in cardiology and as a treatment for diarrhea, diuretic and emetic ${ }^{4}$.

Antioxidants usually prevent toxic materials from developing in the human body through metabolism and reacting with toxic complexes and take the toxic compounds outside human body, this process called ROS attack. Recent studies incrementally support that indigenous antioxidants prove to be useful in preventing the deleterious effects through the increases of body protection via providing it with natural biomedical compounds ${ }^{5}$.

The aim of the study is to 1 ) detect the antimicrobials activity of mangifera extracts on influenza virus H9N2 cultivated on fetal calve kidney (FCK) as well as chicken embryo fibroblast
(CEF) and 2) To detect the cytotoxic activity of the concentrated $10^{-1}, 10^{-2}$ and $10^{-3}$ dilution of mangifera extract on the (FCK) and (CEF) cells.

\section{MATERIALS AND APPARATUS Method}

Preparation of Primary Fetal Cell Culture and Virus Propagation Cells (CCVP), the growth was achieved by the means of a certain method which describe the embryo cells of the chicken's livers using tissue culture flasks by Villegas ${ }^{6}$.

\section{Titration of influenza viruses}

Virus titration was performed as used by Spearman-Karbers method and as described by Villagas?.

\section{Preparation of magnifier}

$1 \mathrm{~g}$ of the dried Pulp of mangifera was added to $10 \mathrm{ml}$ of minimal essential media (MEM). This was then mixed and boiled for five minutes in microwave then centrifuged for $10 \mathrm{~min}$ at $5000 \mathrm{rpm}$. We took the supernatant of 4 groups for the inoculation of mangifera solution: 100ul were added to tissue culture after making different dilutions $1 / 10,1 / 100,1 / 1000,1 / 10000.4$ groups were made:

First: only tissue culture cells without any inoculation to be used as a control

Second: 100ul of different dilutions of mangifera were inoculated to these two kinds of tissue culture to see the effect of mangifera on tissue culture medium.

Third: 100ul of Influenza virus were used to inoculate the two kinds of tissue culture medium to see the cytopathic effect.

Fourth: 100ul of Influenza virus was mixed with 100ul mangifera solution and then filtered with 0.22 um Millipore filter. The tissue culture medium was then inoculated.

The total RNA was extracted using Trizot reagent in accordance to the manufacturers protocol (Ambion). The method was followed by one Taq primer/probe set (Taq Man probe) with forward primer and reverse primer sequences of haemagglutinin glycoprotein region of H9N2 influenza virus to detect the quantity of the virus by the $C T$ value results.

\section{RESULTS}

Titration of the influenza virus (TCID50) $=1 \times 10^{3.5}$ virus $/ \mathrm{ml}$ 


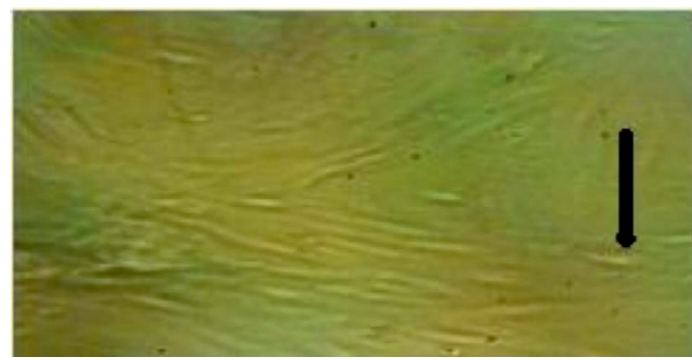

Fig.1. Tissue culture of fetal calves' kidney (normal cell). We can clearly see the cells before being infected with the virus and the mangifera extract.

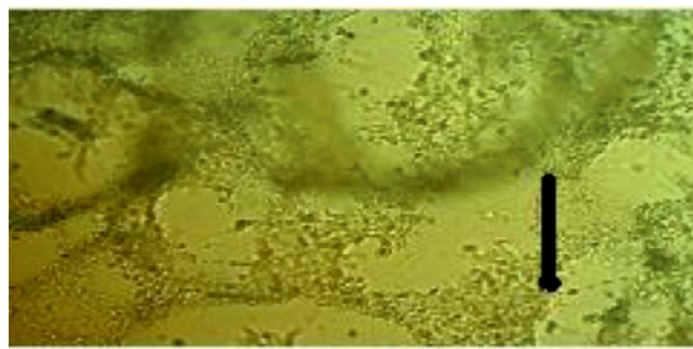

Fig 2. Tissue culture of fetal calves' kidney that infected with Influenza virus after 48 hours. TCID50 of the virus $10^{3.5}$ virus/ $\mathrm{ml}$ (positive control)

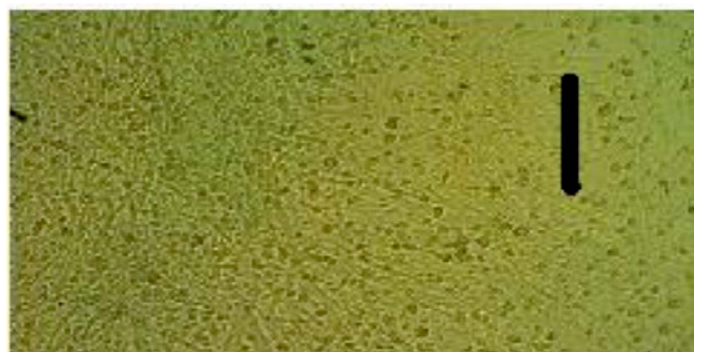

Fig. 3. Tissue culture of chicken fibroblast that infected with Influenza virus which shows visible cytopathic effect (CPE) of the virus on tissue culture. TCID50 of the Influenza virus $10^{3.5}$ virus/ $\mathrm{ml}$ (positive control)

The tissue culture of fetal calves' kidney and chicken fibroblast before and after getting infected with influenza virus.

\section{Results of Real time PCR}

To detect the effects of the mangifera extract on the virus, we used the real time PCR to find the $C T$ value of the effected normal cells (group 3) and the effected cells with the mangifera extract (group 4).

The CT value of the control group 3 (virus + tissue culture cells): 22.2/22.1/22.0/22.1.

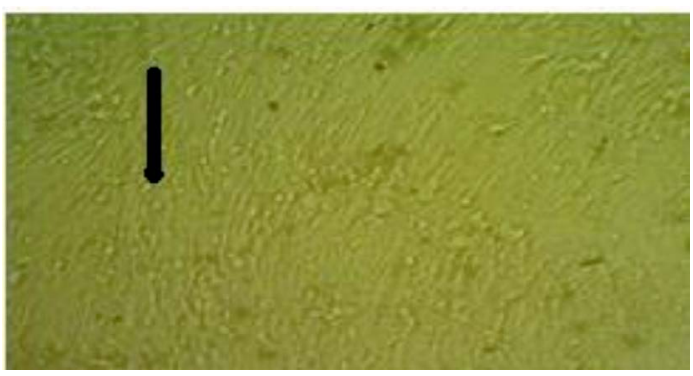

Fig. 4. Tissue culture of chicken fibroblast (Mangifera $10^{-1}$ extract dilution) influenza virus inoculation, very little effect of the virus on the cell (few CPE after 48 hours) comparing with the normal negative control cells.

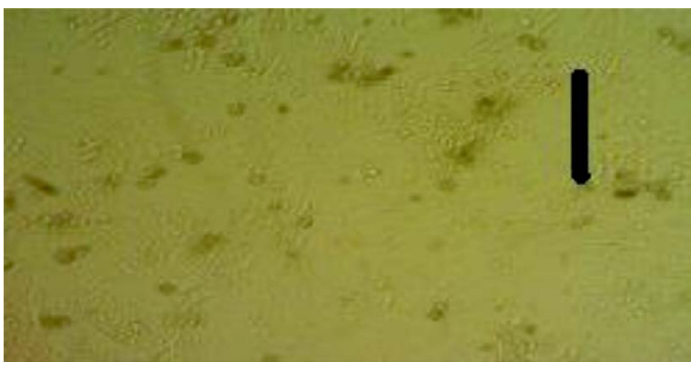

Fig. 5. The antiviral effect of the extract $\left(10^{-2}\right)$ (the CPE appears after 48 hours) of the virus on the cell comparing with the normal negative control cells, lower than the concentration of $10^{-1}$ (more CPE appear).

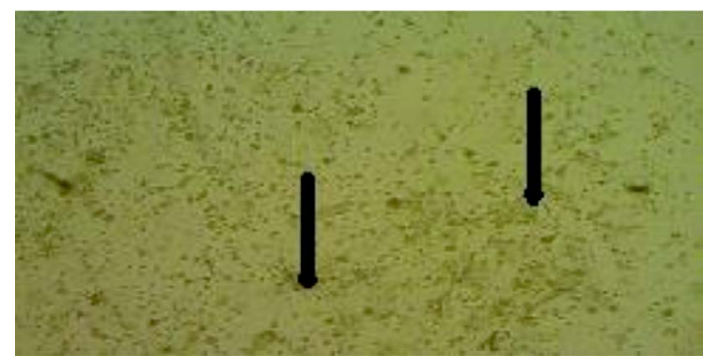

Fig. 6. Normal cell fetal calve kidney treated with concentrated mangifera, the cells die after 24 hours as a result of the cytotoxicity effect of the concentrated extract.

The CT value of the group 4 (virus + mangifera extract + tissue culture cells): 28.4/32.1/30.2/28.1.

\section{DISCUSSION}

Four groups were produced in the study: Group 1 was the negative control group containing chicken embryo fibroblast cells only Group 2 was used to detect the cytotoxicity of the mangifera extract at the concentration of 
$10^{-1}, 10^{-2}, 10^{-3}$ and $10^{-4}$.

Group 3 was to detect the effects of the influenza virus on the chicken embryo fibroblast cells (Ch. E. F.) without adding the mangifera extract.

Group 4 was to detect the natural activity of $10^{-1}$ concentrate mangifera on influenza virus H9N2.

Group 1 negative control (cells only), group 2 appeared the cytotoxic activity on normal cells with the concentrated mangifera extract while it disappeared (no cytotoxic activity) with the concentration diluted to $10^{-1}, 10^{-2}$ and $10^{-3}$. Therefore, the activity of antivirus extract was detected clearly on the concentration of $10^{-1}$ but not on the concentration of $10^{-2}$ and $10^{-3}$, and so we used the negative concentration of $10^{-1}$ which gave the best result for cytotoxic activity of the antivirus.

To confirm these results, we used a real time PCR to detect the quantity of the viral load yield (CT value). The positive control showed the CT value to be around 22 (group 3) which indicate to the high viral load (treated with $10^{-1}$ mangifera extract). The CT value was more than 28 which indicates to a lower percentage of viruses loading and showed the antivirus activity of the extract on influenza virus. The antioxidant activity of Mangifera indica fruit extracts varied between its own samples but proved to be greater than different fruits.

In general Mangifera indica shows superior activity against oxidant comparing with Persea americana despite the region of the samples. Both of them gives a encouraging results for any phytochemical complexes examinations ${ }^{8,9}$. Antiviral activity

Lab tests show high effects of mangiferin, this was considered next to Herpes simplex viruses type 2; mangiferin doesn't show a direct inactivate HSV-2 although the late inhibition event in HSV-2 duplication ${ }^{[10]}$. In vitro mangiferin was moreover has ability to achieve inhibition of HSV-1 virus duplication within cells ${ }^{11}$ and to antagonize the cytopathic effects of HIV ${ }^{12}$.

\section{CONLUSION}

The mangifera extract diluted to $10^{-1}$ showed the highest antiviral activity against the influenza virus H9N2 propagated on tissue culture cells (CEF and FCK), and showed a lower cytotoxicity on those cells also.

\section{ACKNOWLEDGEMENTS}

None.

\section{CONFLICT OF INTEREST}

The author declares that there are no conflict of interest.

\section{REFERENCES}

1. Singh L.B. emango: Botany, cultivation and utilization. Leonardhill (book), London. 76-90, 1960.

2. Abbasi K., Anjum N., Sammi S, Masud T., Ali S. Effect of coatings and packaging material on the keeping quality of mangoes (Mangiferaindica L.) stored at low temperature. Pakistan Journal of Nutrition, 2011; 10: 29-138.

3. Gordon M.H. Significance of Dietary Antioxidants for Health. International Journal of Molecular Science, 2012; 13(1); 173-179.

4. Guha S., Ghosal S., Chattopadyay U. Antitumor, immunomodulatory and anti-HIV effect of mangiferin: A naturally occurring glucosylxan-thone. Chemotherapy, 1996, 42: 443-451.

5. Gupta A., Chaphalkar SR. 2015. Flow cytometric analysis of crude saponin from the leaves of Mangiferaindica and Anthocephaluscadamba for its anti-inflammatory activity. European Journal of Biomedical and Pharmaceutical Sciences, 2015; 2: 163-173.

6. Islam M.R., Mannan1 M.A,. Kabir1 M.H.B., Islam a., Olival K.J. Ethanol extracts of mango leaves. Journal of Bangladesh Agricultural University, 2010; 8: 239-244

7. Villegas P. Procedure for primary chicken embryo liver cells in tissue culture. In: Lab. Manual, avian virus diseases (AM 805). College of Vet. Medicine, University of Georgia, Athens, Ga, 1989; Pp-7.

8. Villegas P., Purchase H.G. A laboratory Manual for the isolation and Identification of Avian Pathogens, 3rd edition, University of Pennsylvania, new Bolton centerkennett, PA. 1989; 187-188

9. Lalisa W.D. Phytochemical Screening and Antioxidant Activity of Selected Mango (MangiferaindicaL.) and Avocado (Persea Americana) Fruits in IlluAbabor Zone, Oromia regional state, Ethiopia, IOSR Journal of Applied Chemistry (IOSR-JAC), 2017; 10(5): 24-28.

10. Shah K.A., Patel M.B., Patel R.J., Parmar P.K. Mangiferalndica (Mango). Pharmacology Review, 2010. 7: 42-48.

11. Zheng M.S., Lu Z.Y. Antiviral effect of mangiferin and isomangiferin on herpes simplex virus. China Medical Journal, 1900; 103: 160-165.

12. Zhu X.M., Song J.X., Huang Z.Z., Whu Y.M., Yu M.J. 1993. Antiviral activity of mangiferin against herpes simplex virus type 2 in vitro. Zhongguo Yao Li XueBao, 1993; 14: $452-454$. 